\title{
Causes and Countermeasures of Multinational Companies' Disinvestment in China
}

\author{
Jun ZHAO \\ Wuhan Textile University, Wuhan, 430073, China \\ email: 282762010@qq.com
}

Key words: Multinational Companies; Disinvest; Causes; Effects; Countermeasures.

\begin{abstract}
This paper first reviews the recent phenomenon that multinational companies in China disinvest and then analyzes the causes of this and the negative effects of this behavior on China and finally proposes countermeasures. Disinvestment of multinational companies means foreign investors (usually referring to foreign merchants or foreign economic organizations) withdraw capital and terminate the production and operating activities entirely or partly in the host country or area. From the perspective of host country, disinvestment of multinational companies is the behavior or the activity that foreign companies remove the investment from the wholly owned enterprises or the joint venture in the host country.
\end{abstract}

\section{Introduction}

In 2009, Nike closed its factory situated in Taicang, Jiangsu province, which is also the only factory situated in China. In October, 2012, the well-known movement brand Adidas from German closed its only directly subordinate factory in Jiangsu, China due to its "strategic consideration of reintegration of global resources". [1] Regarding the whereabouts of this factory, an insider from the Suzhou Industrial Park said that Adidas Suzhou Factory would move to Burma."

In March, 2012, the "Miken" carbon fiber baseball bat from Jarden and the security equipment "First Alert" withdrew their production from Panyu, Guangdong province to US. In 2012, the US earphone producer Sleek Audio closed its factory in Dongguan, China and shifted it back to Florida. The US toy producer Wham-O decided to transfer 50\% of its frisbee and hula-hoop order to US. The US LED light bulb producer Seesmart LED Corporation arranged to transfer back to the US its entire overseas service. Outdoor gear manufacturer Coleman moved some of its service back to the US. High-end kitchenware manufacturer All-Clad Metalcrafters shifted some of its service back to the US. Since March, 2012, [2] Ford Motor Company and Caterpillar Corporation withdrew most of their products from Chinese factories to the US. They opened up factories in contiguous United States to produce auto parts which were originally made in China. The tire and insulation material manufacturing firm Carlisle announced to disinvest from China and changed to invest in the US. On June 21, 2012, the South Korean Daewoo multinational corporation announced to sell Daewoo Cement Factory in Shandong to the Chinese building materials group at 75 billion wons (about 414 million Yuan). Also, the Italian cement group sold its cement service in China to western cement at 504 million Yuan. US ATM (bank ATM) supplier giant NCR shifted from China some of its ATM production to the Columbus of Georgia. In February, 2015, Nikkei reported that Matsushita had liquidated Shandong joint ventures that put up $80 \%$ of the investment and related production activities would be terminated on January 30, 2015. In 2015, Microsoft announced to close down the two cell phone production lines of Nokia in China. [3] In February, 2015, the watch manufacturer Citizen closed its company in Guangzhou. 


\section{Analysis of the causes of disinvestment of multinational companies in China}

According to the structural market flaw theory, the basic condition for direct international investment is that the manufacturer has specific advantages. In transaction cost model, the basic reason for investment is to reduce market transaction cost and increase economic benefit. The international production compromise theory summarizes the basic condition for direct international investment as manufacturer advantage, internalization advantage as well as geographical advantage. The multinational company must make constant adjustments according to the situation to survive and develop if it wants to realize its operational goal of maximal global value. When the subsidiary is faced with poor management or adverse condition, the multinational company might choose to disinvest to raise operation benefit of the entire company if the disinvestment barrier is quite low.

The specific disinvestment reasons for multinational companies in China includes the following several aspects:

The low cost advantage of manufacturing industry is vanishing

For a long time, China has won the global low-end product market depending upon its large idle land and massive population and even free natural resources. However, with the depletion of Chinese natural energy, the rise trend for resource product price is irreversible, leading to the rise of manufacturing industry cost. Meanwhile, the average wages of manufacturing personnel is increasing. At present, the average wage of manufacturing personnel amounts to 2500 Yuan to 3000 Yuan in east China coastal area, but only about 1000 Yuan in Vietnam and even lower in India, only about 600 Yuan.

Boston advisory group published the "manufacturing industry returns to US" which said that Chinese wages by US dollar would grow 15\%-20\% every year and surpass the speed-up of productivity in China. After considering the productivity of US, the once huge labor cost disparity between the China offshore area and some of the low-cost states in US will reduce to $40 \%$ of the present level in 2015. [4] In consideration of the shipping cost and hidden cost as well as the complexity of global supply chain, the cost edge of China becomes small. The senior industrialist Joerg Wuttke of EU Chamber of commerce in China predicts that the China manufacturing cost in 2020 will be 2 times or even 3 times of the present level.

The rise of production cost and gradually tight land supply in China and so on have certain effect on the investment strategy of multinational companies. Because of the US and EU's strategy of encouraging industry regression, some high value-added products of China are faced with competition. Ford Motor Company and Caterpillar Corporation successively withdrew most of their products from factories in China to the US. Nike, Adidas and so on have also been moved from China to Vietnam, Cambodia and other countries.

The drop of the return rate on investment

In 2008, the return rate on investment for multinational companies in China was generally about $8 \%-12 \%$, but dropped to $3 \%$ in 2012, [5]which means that the return rate on investment is lower than the expected and also lower than that in other Asian countries. According to the data of National Bureau of Statistics, of the six industries, i.e. mineral water, canned vegetable, beer, biscuit, candy and milk product, of multinational companies in our country, only the investment return of biscuits and candy are higher than that of our domestic enterprises, while the investment return of the other four industries are negative.

The influence of currency

Since the foreign exchange reform in July, 2005, the rate of RMB to USD has changed from 8.27 to 1 to 6.17 to 1 , which indicates the appreciation scope is $34 \%$. The value of RMB is very high after continuous appreciation and meanwhile the same amount of foreign capital to China can convert to less amount of Renminbi, raising the cost of investment and affecting the motivation of multinational companies to China.

Global financial crisis has an effect on international market

In the wilder world, global financial crisis spread from developing countries to developed countries and constantly deepened. Thus, the real economy globally suffered setbacks and showed 
unprecedented decline and also the global economy changed from excessive liquidity to insufficient liquidity. Under the influence of financial crisis, economy in our country also encountered twists and turns. Because of higher degree of foreign dependence, the export in our country suffered terrible setbacks from global economic depression and the order of processing trade enterprises decreased in a large amount. Among these processing trade enterprises, many are foreign enterprises. The decrease of export order would inevitably cause the enterprises to reduce production scale and some enterprises were even forced to go out of business and disinvest from China because of its weak power and low ability to resist risk.

Policy guidance

The preferential policy of host country is a very important factor to attract multinational companies to make direct investment. Once the corresponding capital-attracting policy changes and affects the interests of multinational companies, disinvestment are very likely to happen. In 2008, our country implemented "tax integration" policy and canceled the preferential tax rate for the foreign-funded enterprises. Tax integration put foreign-funded enterprises in the same competition level as domestic enterprises, which reduced the profit space of foreign enterprises enormously and became a reason for disinvestment. On the other hand, centering on rapid growth of trade surplus and limit from "two high one funded" industry, our country introduced a series of trade policies, such as export rebate rate adjustment, import tariff, limiting processing trade list and so on, which all led to disinvestment of Korean enterprises and also Hong Kong, Macao, Taiwanese enterprises focusing on export trade.

\section{The negative effect on China caused by multinational companies' disinvestment}

Negative effect on employment

When multinational company closes its subsidiary in China, especially the labor-intensive enterprise, numerous workers from this enterprise will face unemployment. If the disinvestment reaches a certain scale, the employment situation in China will worsen and the unemployment rate will rise rapidly and produce tremendous pressure to national economy and politics. Moreover, multinational companies' production and operating activities in China will add product and service demand to Chinese financial industry, insurance industry and transportation and information industry, thus increasing employment of these industries while disinvestment will reduce employment of theses industries.

Negative effect on capital attraction

According to the gravity law of international investment and the lead effect of international investment, if multinational companies disinvest from time to time and the Chinese government does not take effective action to improve this condition, it is very likely to transmit to potential investors the message that the international investment attraction of China is declining and the investment environment is unsatisfactory and is not good for the survival and development of multinational companies. This will definitely affect the confidence of other multinational companies to China, not only blocking further introducing the foreign capital, but also causing the existing multinational companies massively to disinvest.

Negative effect on technology transfer

Multinational companies are not only the main producer and owner of world vanguard technology but also the main spreader in the international technology market. They make the main carrier of international technology shift and the overseas subsidiary of them have remarkable effect on the technology advancement of the host country. If multinational companies disinvest, the technology advancement of host country will be directly affected. Technology transferred to China by the subsidiaries of multinational companies not only includes equipment, intangible asset, technology and management experts, but also includes training given to local employees, involving employees of every level, i.e., simple production operators, complex quality supervisors as well as high-level technical experts and senior management specialists. Disinvestment of multinational companies will affect the flow of scientific personnel and management personnel in China employed by the multinational companies, thus affecting the technology spillover effect brought by 
this kind of flow.

The negative effect on industrial structure

The investment of multinational companies in China pushes the development of Chinese emergent industry, promotes the technological transformation of Chinese traditional industry and speeds up the upgrading process of Chinese industries. Disinvestment of multinational companies will delay the upgrading process of industries. In addition, multinational companies can establish close relationship with Chinese domestic enterprises after investment in China and promote the development of related industry in China through the industrial ripple effect. Instead, the disinvestment of multinational companies will affect the enterprises of the entire industry. From the angle of industry chain transfer, disinvestment of multinational companies will disrupt the order of related Chinese industry, destroy the supply chain contract of related enterprises, produce negative effect on the commodity and service market of China and hinder the development of related Chinese industries in the multiplier effect.

The negative effect on Chinese international payment

The disinvestment of multinational companies will lead to unceasing outflow of capital, which means foreign exchange of the capital project will steadily reduce. In addition, the disinvestment of multinational companies will lead to the phenomenon that the Chinese export trade (including its own export) led by subsidiaries of multinational companies significantly reduces and the corresponding import substitution also reduces and the import increases, enhancing the difficulty of balancing current account in China.

\section{Countermeasures}

Improving the existing Chinese investment environment

According to the data of " global Business environment report in 2014" from the World Bank, China has the worst environment of "obtaining construction permit" and places 185th in the 189 economies, indicating that the "permit" threshold for establishment is the highest. Thus, there is a need to lower this threshold; China's environment of "obtaining bank credit" as capital is the best in the ten evaluation index for business environment, ranking 7rd and the 73rd place is at the low end of global lower and middle income countries and the high end of low-income country, showing that China has larger space of "obtaining bank credit"; Chinese tax revenue lists 120th, but China is the world's second largest economy, which indicates that the operation cost in China is very high and the tax revenue is at the top and thus China should take measures to reduce tax and improve the investment environment; the investment protection and bankruptcy protection in China are listed 98th and 78th respectively, falling behind the developed countries and upper-middle-income countries, showing that these aspects need deep reform. From World Bank's ten evaluation index for business environment, we find that the investment environment in China doesn't match its status of second largest economy and biggest trading power and needs improving.

Adjustment of foreign capital policy

First, we should adjust foreign capital policy to maintain the stability of the capital inflow and outflow, making it the definite factor for the positive cycle of national economy. Meanwhile,we should adjust the excessively centralized structure of foreign investor and avoid the capital inflow being seriously affected by the economic fluctuation of some country or some area.

Next, we should take necessary prior-control. Since it is hard for the host country to take effective measures to stop the disinvestment that has already begun after the event, strengthening the prior-control of the foreign capital flow becomes an effective way for us to avoid multinational companies' disinvestment and also its negative impact. 


\section{Conclusion}

Finally, we must take advantage of the multi-level characteristic of Chinese industry, adopt explicit policy for industry preference, change foreign capital withdrawal to industrial transfer in China and meanwhile provide more complete and real investment information for the multinational companies to reduce the disinvestment caused by asymmetric information.

\section{References}

[1] World commodity exchange center. The production costs in China and America are approaching and whether the disinvestment of American company from Zhujiang Delta is representative [EB/OL]. http://blog.sina.com.cn/s/blog_89b4011b0100zgbn.html.

[2] Li Qing. US enterprises return home from China to produce and Chinese production cost increases [EB/OL]. http://news.sohu.com/20111031/n324030432.shtml

[3] Zhang Lili. The study of causes, influence, and measures of multinational companies' disinvestment from China [J]. Inquiry into economic issues. 2009(1): 60-65.

[4] Zuo Rui. Study on the motivation and strategic orientation of the wholly foreign-funded companies[J].Journal of district economy. 2006(05):34-39

[5] Liu Shouxian. Research on causes and countermeasures for the united states multinational companies [J]. Journal of Beijing Institute of Printing. 2011(03): 12-19 